\title{
Pengaruh Rasio Profitabilitas, Likuiditas, Solvabilitas, Struktur Kepemilikan Institusional, dan Struktur Kepemilikan Manajerial, Terhadap Kesulitan Keuangan (Dengan Model Altman Z-Score)
}

(Studi Pada Perusahaan Manufaktur Yang Terdaftar di Bursa Efek Indonesia Tahun 2017-2019)"

\author{
Rini Susanti \\ Universitas Wijaya Kususma Surabaya \\ rinisusanti07061999@gmail.com
}

\author{
Wiwin Wahyuni 2 \\ Universitas Wijaya Kususma Surabaya \\ wiwinwahyuni@uwks.ac.id
}

\begin{abstract}
This study aims to see how the development of the financial performance of manufacturing companies listed on the Indonesia Stock Exchange for the last 3 years from 2017 to 2019 using the financial ratio analysis method. The financial ratios used are Profitability, Liquidity, Solvency, Institutional Ownership Structure, and Managerial Ownership Structure. The results showed that in general the financial ratios of manufacturing companies listed on the Indonesia Stock Exchange fluctuated, but among them there were several companies that had good financial ratios and poor financial ratios.
\end{abstract}

Keywords Financial Ratios, Financial Performance

\section{PENDAHULUAN}

Perkembangan posisi keuangan memiliki arti yang sangat penting bagi perusahaan. Untuk melihat sehat atau tidaknya suatu perusahaan tidak hanya dapat dinilai dari keadaan fisiknya saja, misalnya dilihat dari gedung, pembangunan atau ekspansi. Faktor terpenting untuk dapat melihat perkembangan suatu perusahaan terletak dalam unsur keuangannya, karena dari unsur tersebut juga dapat mengevaluasi apakah kebijakan yang ditempuh suatu perusahaan sudah tepat atau belum, mengingat sudah begitu kompleksnya permasalahan yang dapat menyebabkan kebangkrutan dikarenakan banyaknya perusahaan yang akhirnya gulung tikar karena faktor keuangan yang tidak sehat. Dengan keadaan sekarang ini, dimana persaingan ketat dibidang perekonomian sudah mulai masuk ke Negara Indonesia, maka jika seorang manajer perusahaan tidak memperhatikan factor kesehatan keuangan dalam perusahaannya, mungkin saja akan terjadi kebangkrutan seperti yang telah dikemukakan sebelumnya. Analisis keuangan pada dasarnya ingin melihat prospek dan risiko perusahaan. Prospek bisa dilihat dari tingkat keuntungan (profitabilitas) dan risiko bisa dilihat dari kemungkinan perusahaan mengalami kesulitan keuangan atau mengalami kebangkrutan (Mamduh M. Hanafi, 2005:21).

Atas dasar masalah tersebut maka penulis ingin melakukan suatu penelitian dengan judul "Pengaruh Rasio Profitabilitas, Likuiditas, Solvabilitas, Struktur Kepemilikan Institusional, dan Struktur Kepemilikan Manajerial Terhadap Kesulitan Keuangan (Dengan Model Altman Z-Score) (Studi Pada Perusahaan Manufaktur Yang Terdaftar di Bursa Efek Indonesia Tahun 2017-2019)". 
Rumusan masalah pada penelitian ini adalah, apakah profitabilitas likuiditas solvabilitas kepemilikan institusional dan kepemilikan manajerial berpengaruh terhadap kesulitan keuangan pada perusahaan manufaktur yang terdaftar di Bursa Efek Indonesia tahun 2017-2019.

\section{METODOLOGI PENELITIAN}

Salah satu fungsi akuntansi adalah menyajikan laporan-laporan periodik untuk manajemen, investor, kreditur, dan pihak-pihak lain diluar perusahaan. Laporan keuangan utama yang dihasilkan dari proses akuntansi adalah neraca, laporan rugi-laba, dan juga laporan aliran kas. Neraca dibuat dengan maksud untuk menggambarkan posisi keuangan suatu organisasi pada suatu saat tertentu. Laporan rugi-laba menggambarkan hasil-hasil usaha yang dicapai dalam suatu periode waktu tertentu, biasanya meliputi periode satu tahun, sedangkan laporan aliran kas menggambarkan jumlah kas yang masuk dan juga jumlah kas yang keluar dalam suatu perusahaan (Al Haryono Jusup, 2005 : 21). Disamping ketiga laporan yang pokok tersebut, juga dihasilkan laporan pendukung seperti laporan laba ditahan, laporan perubahan modal sendiri, dan diskusi-diskusi oleh pihak manajemen (Mamduh M. Hanafi, 2005 : 49).

Rasio keuangan merupakan alat yang dinyatakan dalam artian relative maupun absolute yang menjelaskan hubungan tertentu antara angka yang satu dengan angka yang lainnya dalam laporan keuangan (Syafaruddin Alwi, 1994:107). Rasio-rasio keuangan mungkin dihitung berdasarkan angka-angka yang ada dalam neraca saja, dalam laporan laba rugi saja, atau pada neraca dan laporan laba rugi. Setiap analisis keuangan bisa saja merumuskan rasio tertentu yang dianggap mencerminkan aspek tertentu (Suad Husnan, 2002:69).

Isu corporate governance dilatar belakangi oleh agency theory yang menyatakan bahwa permasalahan agency muncul ketika kepengurusan suatu perusahaan terpisah dari kepemilikannya. Untuk mengurangi tingkat masalah keagenan yang yang timbul pada suatu perusahaan adalah dengan menerapkan tata kelola perusahaan yang baik (good corporate governance). Penelitian terdahulu oleh Emrinaldi (2007) menyatakan bahwa terdapat hubungan signifikan dan negatif antara kepemilikan manajerial dengan perusahaan yang mengalami kesulitan keuangan. Hal ini berbeda dengan Ghozali dan Sinaga (2006) yang meneliti hubungan antara pengurus pemilik bank dan kebangkrutan bank di Indonesia yang menyatakan bahwa prosentase kepemilikan manjerial, yaitu kepemilikan oleh komisaris mempunyai hubungan positif dan signifikan terhadap kemungkinan terjadinya kebangkrutan. Penelitian Emrinaldi (2007) yang menyatakan bahwa peningkatan kepemilikan institusional dalam perusahaan akan mendorong semakin kecilnya potensi kesulitan keuangan. Hal ini sejalan dengan penelitian Abdullah (2006) di Malaysia yang menyatakan bahwa kepemilikan oleh non executive director mempunyai hubungan signifikan dan negatif pada perusahaan yang mengalami kondisi financial distress. Namun, hasil berbeda terjadi pada penelitian yang dilakukan oleh Parulian (2007) yang tidak dapat membuktikan adanya hubungan antara kepemilikan institusional dengan financial distress. Berdasarkan tinjauan pustaka dan penelitian terdahulu di atas, maka dapat digambarkan kerangka penelitian sebagai berikut: 


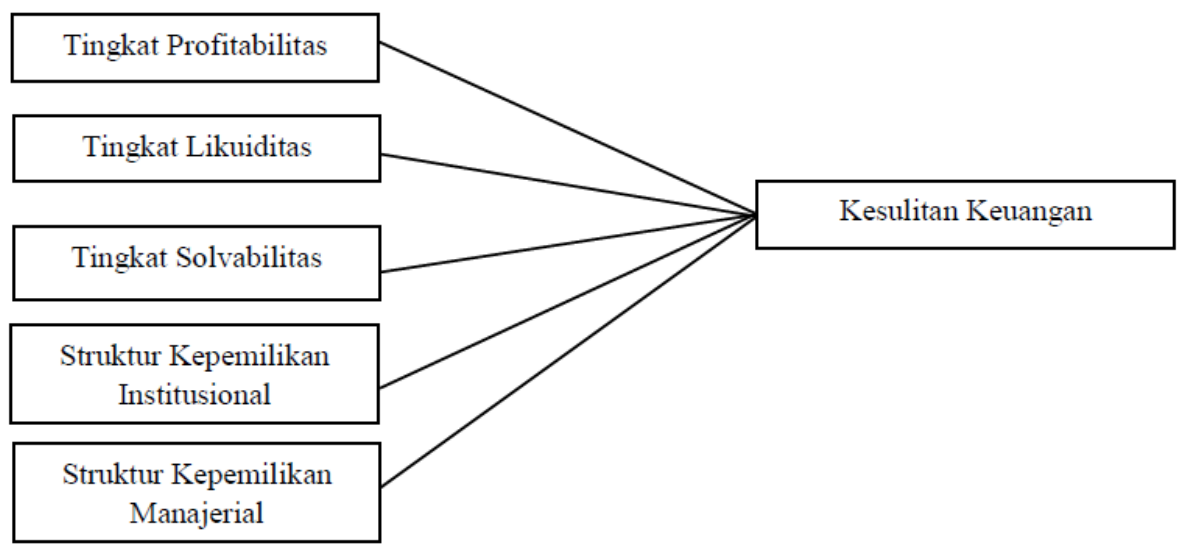

Penelitian ini digunakan untuk mengukur kesulitan keuangan pada perusahaan manufaktur yang terdaftar di Bursa Efek Indonesia pada tahun 2017-2019 ditinjau dari rasio profitabilitas, likuiditas, solvabilitas, struktur kepemilikan institusional, dan struktur kepemilikan manajerial dengan menggunakan model Altman Z-Score. Sampel penelitian ini ditentukan berdasarkan purposive sampling yang berarti pemilihan sampel berdasarkan kriteria tertentu. Sampel yang digunakan dalam penelitian ini adalah perusahaan yang terdaftar di Bursa Efek Indonesia dengan periode laporan keuangan tahun 2017-2019.

Variabel rasio keuangan yang digunakan dalam penelitian ini yaitu:

a. Tingkat profitabilitas kemampuan perusahaan dalam memperoleh laba keuntungan. Untuk menghitung tingkat profitabilitas dapat digunakan rumus sebagai berikut:

$$
\text { Return on Asset= }=\frac{\text { Laba Sebelum Pajak }}{\text { Total Aktiva }} \times 100 \%
$$

b. Tingkat likuiditas merupakan kemampuan untuk merubah aktiva menjadi kas atau kemampuan untuk memperoleh kas jangka pendek secara konfensional dianggap periode hingga satu tahun (Jhon J. Wild,K.R. Subramanyam, Robert F.Halsey, Analisa Laporan Keuangan, Salemba empat, Jakarta, 2005). Untuk menghitung tingkat likuiditas dapat digunakan rumus sebagai berikut:

$$
\text { Current Ratio }=\frac{\text { Aktiva Lancar }}{\text { Hutang Lancar }} \times 100 \%
$$

c. Tingkat solvabilistas menunjukkan kemampuan berulang untuk menghasilkan kas dari orperasi (laba). Untuk menghitung tingkat solvabilitas dapat digunakan rumus sebagai berikut:

$$
\text { Debt to Asset Ratio }=\frac{\text { Jumlah Hutang }}{\text { Jumlah Aktiva }} \times 100 \%
$$

d. Struktur kepemilikan

Kepemilikan institusional merupakan persentase saham yang dimiliki oleh institusi dari keseluruhan saham perusahaan yang beredar. Dalam penelitian ini kepemilikan institusional diukur dengan besar prosentase kepemilikan institusional di dalam perusahaan amatan (Emrinaldi, 2007). Untuk menghitung kepemilikan institusional dapat digunakan rumus sebagai berikut:

$$
\mathrm{NNST}=\frac{\text { Jumlah saham dimiliki institusi }}{\text { Jumlah saham beredar }} \times 100 \%
$$


Kepemilikan manajerial didefinisikan sebagai kepemilikan saham yang dimiliki oleh manajemen. Kepemilikan manajerial dalam penelitian ini diukur dari prosentase tingkat kepemilikan oleh dewan direksi dan dewan komisaris (Wardhani, 2006). Untuk menghitung kepemilikan manajerial dapat digunakan rumus sebagai berikut:

\section{e. Financial Distress}

$$
\text { MNJR }=\frac{\text { Jumlah saham dimiliki manajer }}{\text { Jumlah saham beredar }} \times 100 \%
$$

Financial distressatau kesulitan keuangan adalah suatu kondisi keuangan perusahaan sedang dalam masalah, krisis atau tidak sehat yang terjadi sebelum perusahaan mengalami kebangkrutan.

$\mathrm{Z}=0,717 \mathrm{X} 1+0,847 \mathrm{X} 2+3,107 \mathrm{X} 3+0,420 \mathrm{X} 4+0,998 \mathrm{X} 5$

Dimana:

$\mathrm{Z}=$ Indeks

$\mathrm{X} 1=$ Modal Kerja/ Total Aset

$\mathrm{X} 2$ = Laba Ditahan/ Total Aset

X3 = Laba sebelum bunga dan pajak/ Total Aset

X4 = Nilai pasar modal/ Total Kewajiban

X5 = Penjualan/ Total Aset

Pada penelitian ini, yang menjadi populasi adalah perusahaan manufaktur yang terdaftar di Bursa Efek Indonesia. Sedangkan, sampel adalah bagian dari jumlah dan kararteristik yang dimiliki oleh populasi tersebut (Ibi). Sampel yang digunakan dalam penelitian ini adalah laporan keuangan perusahaan manufaktur yang terdaftar di Bursa Efek Indonesia berdasarkan pada Rasio Likuiditas, Solvabilitas, Profitabilitas dan Sruktur Kepemilikan.

Uji Asumsi Klasik

a. Uji Normalitas

Uji normalitas data bertujuan untuk mengetahui apakah data dalam sebuah model regresi terdistribusi normal atau tidak. Dalam penelitian ini menggunakan uji Kolmogorov Smirnov dengan ketentuan jika probabilitas lebih besar dari 0,05 maka variabel tersebut telah terdistribusi normal.

b. Uji Autokorelasi

Uji Autokorelasi memiliki tujuan untuk menguji apakah model regresi linier terdapat korelasi antara kesalahan penganggu dengan periode $t$ dengan kesalahan penggangu pada t-1 (sebelumnya) Jika terjadi korelasi, maka dikatakan problem autokorelasi. Untuk mendeteksi ada atau tidaknya autokorelasi, dilakukan dengan uji Durbin-Watson atau DW test (Gzohali, 2009). Hipotesis yang diujikan dengan DW test:

Ho $=$ tidak terdapat autokorelasi $(\mathrm{r}=0)$

$\mathrm{HA}=$ terdapat autokorelasi $(\mathrm{r} \neq 0)$

Menurut Santoso (2010) Pengambilan keputusan mengenai ada atau tidaknya utokorelasi adalah sebagai berikut:

- Bila angka DW terletak di bawah -2 berarti terdapat autokorelasi positif

- Bila angka DW terletak di antara -2 sampai +2 tidak ada autokorelasi

- Bila angka DW terletak di atas +2 terdapat autokorelasi negatif

Analisis regresi linier berganda dalam penelitian ini digunakan untuk menyatakan hubungan fungsional antara variabel independen dan variabel dependen. 
Analisi regresi digunakan terutama untuk tujuan peramalan dalam model tersebut ada sebuah variabel dependen dan berapa variabel independen. Adapun persamaan yang digunakan adalah :

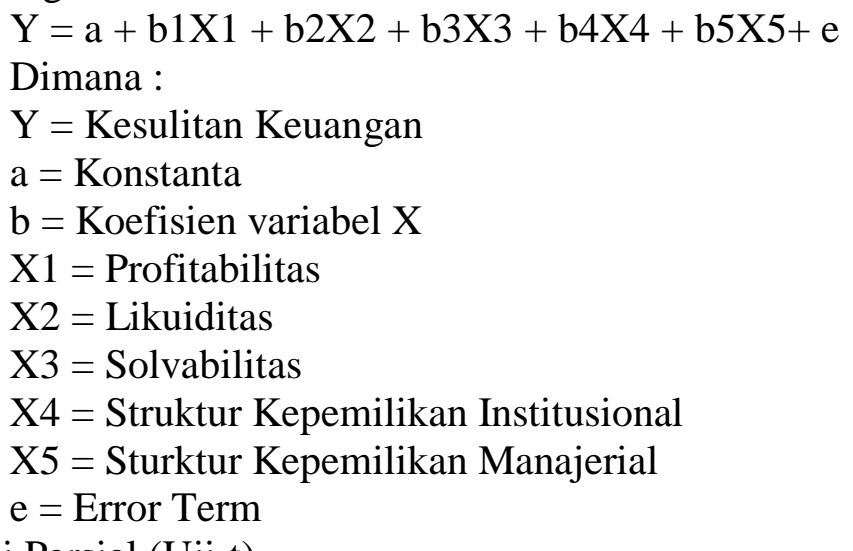

Uji Parsial (Uji-t)

Uji t merupakan uji signifikan pengaruh setiap variabel antara variabel terhadap variabel dependen. Untuk itu digunakan nilai probabilitas. Apabila nilai probabilitas kurang dari 0,05 maka dapat disimpulkan bahwa variabel bebas memliki pengaruh yang signifikan terhadap variabel terikat, jika nilai probabilitas lebih besar dari 0,05 maka disimpulkan bahwa variabel bebas tidak signifikan terhadap variabel terikat.

Uji F

Uji F merupakan pengujian variabel independen secara bersama terhadap mempengaruhi variabel terikat maka dapat dilakukan dengan membandingkan nilai $\mathrm{F}$ hitung dengan nilai $\mathrm{F}$ tabel.

1. Jika nilai $\mathrm{F}$ hitung $\leq \mathrm{F}$ tabel, maka Ha diterima.

2. Jika nilai $\mathrm{F}$ hitung $\geq \mathrm{F}$ tabel, maka Ho ditolak.

Uji Determinasi (R2)

Uji Determinasi digunakan secara keseluruhan untuk mengukur ketepatan yang paling baik dari analisis regresi berganda. Apabila R2 mendekati suatu maka dapat dikatakan semakin kuat model tersebut menerangkan variasi variabel indepen terhadap variabel dependen.

\section{HASIL PENELITIAN}

Objek penelitian ini adalah perusahaan sektor manufaktur yang terdaftar di Bursa Efek Indonesia (BEI) pada periode 2017-2019. Selama periode penelitian terdapat 234 sampel yang akan diuji. Dalam menentukan jenis sampel yang digunakan dalam penelitian ini yaitu menggunakan teknik perposive sampling yaitu metode penarikan sampel yang dilakukan dengan kriteria tertentu. Sampel ini diambil secara purposive sampling. Berdasarkan pada kriteria pengambilan sampel, maka jumlah sampel yang digunakan dalam penelitian ini adalah 78 perusahaan manufaktur.

\section{Uji Normalitas}

Uji normalitas bertujuan untuk mengetahui apakah data dalam sebuah model regresi, variabel independen maupun variabel dependen mempunyai distribusi normal atau tidak. Pengujian normalitas ini menggunakan uji statistic

Kolmogorov-Smirnov Test dengan hipotesis:

$\mathrm{H}^{0}$ : data residual berdistribusi normal

$\mathrm{H}^{1}$ : data residual tidak berdistribusi normal 
Uji Normalitas

\begin{tabular}{|c|c|}
\hline $\mathbf{N}$ & Asymp. Sig. (2-tailed) \\
\hline 234 & $.000^{\mathrm{c}}$ \\
\hline
\end{tabular}

Apabila nilai signifikannya lebih besar dari 0,05 , maka $\mathrm{H}^{0}$ diterima, sedangkan jika nilai signifikanya lebih kecil dari 0,05 maka $\mathrm{H}^{0}$ ditolak. Dari hasil uji normalitas diatas, dapat disimpulkan bahwa variabel yang digunakan dalam penelitian ini yaitu Profitabilitas (ROA), Likuiditas (Current Ratio), Solvabilitas (DER), Struktur Kepemilikan Institusional, Struktur Kepemilikan Manajerial dan Kesulitan Keuangan memiliki tinggkat signifikan dibawah 0,05 yaitu 0,000 artinya data yang digunakan dalam penelitian ini berdistribusi normal dan menunjukkan bahwa model regresi layak dipakai karena memenuhi kriteria asumsi normalitas.

\section{Uji Autokorelasi}

Uji Autokorelasi dilakukan untuk menguji apakah dalam sebuah model regresi linier terdapat korelasi antara kesalahan penggangu pada periode $t$ dengan kesalahan pada periode t-1 sebelumnya). Untuk mengetahui autokorelasi dalam penelitian ini, maka digunakan uji Durbin Watson (DW).

\section{Uji Autokorelasi}

\begin{tabular}{|c|c|}
\hline Model & Durbin-Watson \\
\hline 1 & 1.100 \\
\hline
\end{tabular}

Pengambilan keputusan ada atau tidaknya autokorelasi berdasarkan hasil penelitian yang menyebutkan bahwa nilai DW $=1,106$. Hasil regresi dengan nilai signifikansi $0,05(\alpha=0,05)$ dengan jumlah variabel independen adalah $5(\mathrm{k}=5)$, dan banyaknya data $(\mathrm{n}=234)$, maka $(\mathrm{k} ; \mathrm{n})=(5 ; 234)$. Maka ditemukan nilai dL sebesar 1,74873 dan dU sebesar 1,81945. Nilai Durbin Watson (d) sebesar 1,100 lebih kecil dari batas atas (dU) yakni 1,81945 dan dari $(4-\mathrm{dU})=(4-1,81945=$ $2,18055)$.

\section{Analisis Regresi Linier Berganda}

Analisis regresi digunakan untuk mengetahui hubungan antara variable independen dengan variabel dependen apakah masing-masing variabel independen berhubungan positif atau variabel dan untuk memprediksi nilai dari variabel dependen apabila nilai variabel independen mengalami kenaikan atau penurunan. Berikut ini hasil perhitungan menggunakan SPSS16 Analisis Regresi Linier Berganda

\begin{tabular}{|ll|r|}
\hline \multicolumn{1}{|c|}{ Model } & B \\
\hline 1 (Constant) & .782 \\
& Profitabilitas & .104 \\
Likuiditas & 1.599 \\
Solvabilitas & -.257 \\
Struktur Kepemilikan Institusional & .170 \\
Struktur Kepemilikan Manajerial & .129 \\
\hline
\end{tabular}

Berdasarkan hasil test diatas dapat diperoleh persamaan regresi linier berganda sebagai berikut:

$Y=0,782+0,104 X^{1}+1,599 X^{2}-0,257 X^{3}+0,170 X^{4}+0,129 X^{5}+e$

Dimana : 


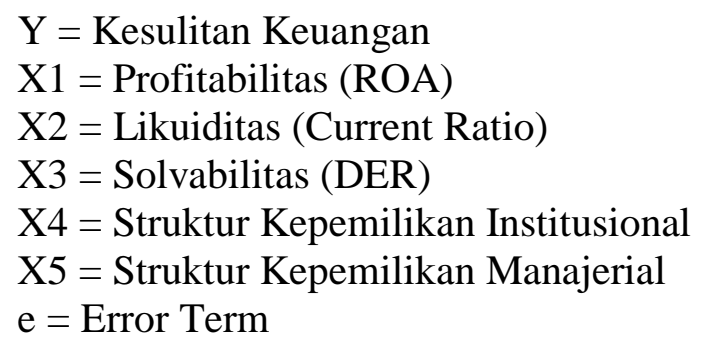

\section{Uji Simultan (Uji F)}

Uji $\mathrm{F}$ bertujuan untuk menguji signifikan pengaruh variabel rasio profitabilitas, likuiditas, solvabilitas, struktur kepemilikan institusional dan struktur kepemilikan manajerial terhadap kesulitan keuangan secara bersamasama. Berikut uji $\mathrm{F}$ yang diolah menggunakan SPSS versi 16.

\section{Uji F}

\begin{tabular}{|ll|c|c|c|}
\hline \multicolumn{1}{|c|}{ Model } & F & Sig. & Kesimpulan \\
\hline $\begin{array}{l}1 \\
\text { Regression } \\
\text { Residual }\end{array}$ & 47.493 & .000 & Signifikan \\
\hline
\end{tabular}

Berdasarkan pengujian dari tabel 4.8 dapat kita lihat bahwa dapat diketahui Fhitung sebesar 47,493 dan dengan nilai signifikan sebesar 0,000, karena nilai signifikan kurang dari 0.05 maka $\mathrm{H}^{\text {a }}$ diterima dan $\mathrm{H}^{\mathrm{o}}$ ditolak. Jadi dapat dikatakan bahwa ada pengaruh signifikan antara variabel Profitabilitas (Return On Assets), Likuiditas (Current Ratio), Solvabilitas (Debt to Assets Ratio), Struktur Kepemilikan Institusional, dan Struktur Kepemilikan Manajerial terhadap Kesulitan Keuangan.

\section{Uji Parsial (Uji-t)}

Uji t digunakan untuk mengetahui pengaruh masing-masing variabel bebas yaitu likuiditas, solvabilitas dan profitabilitas terhadap kesulitan keuangan. Adapun hasil yang diperoleh adalah sebagai berikut:

\begin{tabular}{|l|r|r|r|l|}
\multicolumn{1}{|c}{ Uji t } \\
\multicolumn{1}{|c|}{ Model } & \multicolumn{1}{c|}{ B } & \multicolumn{1}{c|}{ T } & \multicolumn{1}{c|}{ Sig. } & Kesimpulan \\
\hline (constan) & .782 & 4.644 & .000 & \\
Profitabilitas & .104 & 2.436 & .016 & Berpengaruh \\
Likuiditas & 1.599 & 13.226 & .000 & Berpengaruh \\
Solvabilitas & -.257 & -1.923 & .056 & Tidak Berpengaruh \\
Struktur Kepemilikan Institusional & .170 & 1.512 & .132 & Tidak Berpengaruh \\
Struktur Kepemilikan Manajerial & .129 & 1.220 & .224 & Tidak Berpengaruh \\
\hline
\end{tabular}

\section{Uji Determinasi $\left(R^{2}\right)$}

Koefisien $\left(\mathrm{R}^{2}\right)$ digunakan untuk mengetahui persentase pengaruh variabel independen secara serentak terhadap variabel dependen. Dalam perhitungan statistik $\mathrm{R}^{2}$ yang digunakan adalah adjusted $\mathrm{R}$ square. Adjusted $\mathrm{R}$ square adalah suatu indikator yang digunakan untuk mengetahui pengaruh penambahan suatu variabel independent ke dalam suatu persamaan regresi. Nilai adjusted $\mathrm{R}^{2}$ telah dibebaskan dari pengaruh derajat 
kebebasan (degree of freedom) yang berarti nilai tersebut telah benar-benar menunjukkan bagaimana pengaruh variabel independen terhadap variabel dependen.

Uji Determinasi $\left(\mathbf{R}^{2}\right)$

\begin{tabular}{|c|c|}
\hline Model & $\begin{array}{c}\text { Adjust R } \\
\text { Square }\end{array}$ \\
\hline 1 & .503 \\
\hline
\end{tabular}

\section{PEMBAHASAN}

Berdasarkan deskriptif laporan keuangan perusahaan manufaktur tahun 20172019 dilihat dari rasio profitabilitas, likuiditas, solvabilitas, struktur kepemilikan institusional dan struktur kepemilikan manajerial diatas terdapat beberapa pengaruh terhadap tingkat kesehatan perusahaan manufaktur yang terdaftar di Bursa Efek Indonesia.

\section{Hubungan Profitabilitas dengan Financial Distress}

Berdasarkan hasil uji hipotesis menunjukkan bahwa variabel profitabilitas (ROA) memiliki tingkat signifikansi sebesar 0,016. Hal ini berarti $\mathrm{H} 1$ diterima karena tingkat signifikansi yang dimiliki variabel profitabilitas lebih kecil dari 0,05. Dapat disimpulkan bahwa profitabilitas berpengaruh signifikan terhadap kesulitan keuangan. Hasil penelitian ini tidak sesuai dengan penelitian Amilia dan Kristijafi (2003), yang menyebutkan bahwa profitabilitas memiliki pengaruh yang negatif dan signifikan terhadap kesulitan keuangan. Berdasarkan hasil regresi untuk rasio profitabilitas menunjukkan bahwa nilai coefficient $=0,104$ dan nilai $t$ hitung sebesar 2,436 dengan nilai signifikan lebih kecil dari 0,05 $(0,016<0,05)$. Hasil menunjukkan nilai coefficient mengalami 80 peningkatan dan berpengaruh positif. Profitabilitas memiliki pengaruh yang positif dan signifikan terhadap kesulitan keuangan.

\section{Hubungan Likuiditas dengan Financial Distress}

Berdasarkan hasil uji hipotesis menunjukkan bahwa variabel likuiditas (Current Ratio) memiliki tingkat signifikansi sebesar 0,000. Hal ini berarti $\mathrm{H} 2$ diterima karena tingkat signifikansi yang dimiliki variabel likuiditas lebih kecil dari 0,05. Dapat disimpulkan bahwa likuiditas berpengaruh signifikan terhadap kesulitan keuangan. Hasil penelitian ini sesuai dengan penelitian Amilia dan Kristijafi (2003), yang menyebutkan bahwa likuiditas memiliki pengaruh yang positif dan signifikan terhadap kesulitan keuangan. Berdasarkan hasil regresi untuk rasio likuiditas menunjukkan bahwa nilai coefficient $=1,599$ dan nilai t hitung sebesar 13,226 dengan nilai signifikan lebih kecil dari $0,05(0,000<0,05)$. Hasil menunjukkan nilai coefficient mengalami penurunan dan berpengaruh positif. Likuiditas memiliki pengaruh yang positif dan signifikan terhadap kesulitan keuangan.

\section{Hubungan Solvabilitas dengan Financial Distress}

Berdasarkan hasil uji hipotesis menunjukkan bahwa variabel solvabilitas (DAR) memiliki tingkat signifikansi sebesar 0,056. Hal ini berarti $\mathrm{H} 3$ ditolak karena tingkat signifikansi yang dimiliki variabel likuiditas lebih besar dari 0,05. Dapat disimpulkan bahwa solvabilitas tidak berpengaruh signifikan terhadap kesulitan keuangan. Hasil penelitian ini tidak sesuai dengan penelitian Iramani (2007), yang menyebutkan bahwa solvabilitas memiliki pengaruh yang positif dan signifikan terhadap kesulitan keuangan. 
Berdasarkan hasil regresi untuk rasio solvabilitas menunjukkan bahwa nilai coefficient $=$ $-0,257$ dan nilai $t$ hitung sebesar $-1,923$ dengan nilai signifikan lebih besar dari 0,05 $(0,056>0,05)$. Hasil menunjukkan nilai coefficient mengalami penurunan dan berpengaruh positif. Solvabilitas tidak memiliki pengaruh signifikan terhadap kesulitan keuangan.

\section{Hubungan Struktur Kepemilikan Institusional terhadap Financial Distress}

Berdasarkan hasil uji hipotesis menunjukkan bahwa variabel struktur kepemilikan institusional memiliki tingkat signifikansi sebesar 0,132. Hal ini berarti H4 ditolak karena tingkat signifikansi yang dimiliki variabel likuiditas lebih besar dari 0,05. Dapat disimpulkan bahwa struktur kepemilikan institusional tidak berpengaruh signifikan terhadap kesulitan keuangan. Hasil penelitian ini sesuai dengan penelitian Anandhita Ira Sabrinna (2010), yang menyebutkan bahwa struktur kepemilikan institusional tidak memiliki pengaruh dan hubungan signifikan terhadap kesulitan keuangan. Berdasarkan hasil regresi untuk struktur kepemilikan institusional menunjukkan bahwa nilai coefficient $=0,170$ dan nilai t hitung sebesar 1,220 dengan nilai signifikan lebih besar dari $0,05(0,132>0,05)$. Struktur kepemilikan institusional tidak memiliki pengaruh signifikan terhadap kesulitan keuangan.

\section{Hubungan Struktur Kepemilikan Manajerial terhadap Financial Distress}

Berdasarkan hasil uji hipotesis menunjukkan bahwa variabel struktur kepemilikan manajerial memiliki tingkat signifikansi sebesar 0,224. Hal ini berarti H5 ditolak karena tingkat signifikansi yang dimiliki variabel struktur kepemilikan manajerial lebih besar dari 0,05. Dapat disimpulkan bahwa struktur kepemilikan manajerial tidak berpengaruh signifikan terhadap kesulitan keuangan. Hasil penelitian ini sesuai dengan penelitian Anandhita Ira Sabrinna (2010), yang menyebutkan bahwa struktur kepemilikan manajerial tidak memiliki pengaruh dan hubungan signifikan terhadap kesulitan keuangan. Berdasarkan hasil regresi untuk struktur kepemilikan manajerial menunjukkan bahwa nilai coefficient $=0,129$ dan nilai t hitung sebesar 1,220 dengan nilai signifikan lebih besar dari 0,05 $(0,224>0,05)$. Hasil menunjukkan struktur kepemilikan manajerial tidak berpengaruh terhadap kesulitan keuangan.

\section{KESIMPULAN}

Berdasarkan hasil analisis dan pembahasan yang telah dilakukan , maka dapat di ambil kesimpulan sebagai berikut:

Profitabilitas berpengaruh secara positif terhadap financial distress perusahaan manufaktur yang terdaftar di Bursa Efek Indonesia. Likuiditas berpengaruh secara positif terhadap financial distress perusahaan manufaktur yang terdaftar di Bursa Efek Indonesia. Solvabilitas tidak berpengaruh terhadap financial distress perusahaan manufaktur yang terdaftar di Bursa Efek Indonesia. Struktur Kepemilikan Institusional tidak berpengaruh terhadap financial distress perusahaan manufaktur yang terdaftar di Bursa Efek Indonesia. Struktur Kepemilikan Manajerial tidak berpengaruh terhadap financial distress perusahaan manufaktur yang terdaftar di Bursa Efek Indonesia.

\section{DAFTAR PUSTAKA}

Almilia dan Kristijadi, 2003, rasio-rasio keuangan untuk memprediksi financial distress. Anandhita Ira Sabrinna, 2010, Bambang Riyanto, 2001:193, pengaruh corporate governance dan masalah optimum modal. 
Avina, Putri, Adam, Mayar, Afriyenti. "Pengaruh Rasio Likuiditas, Solvabilitas, Dan Rentabilitas Terhadap Return Saham Pada Perusahaan LQ45 Yang Terdaftar di BEI 2014-2018”. Jurnal Eksplorasi Akuntansi Vol. 2, No 1, Seri D, Februari 2020, Hal 2391-2406.

Ahmadi. Edy Anas, Herwidyaningtyas, Fristina Bhakti, Fatimah. Siti. 2020. The Influence Of Organizational Culture, Work Motivation, And Job Satisfaction On Management Lecturer Performance (Empirical Study At Higher Education In The Residency Of Bojonegoro. Journal Of Industrial Engineering \& Management Research. Jilid 1. Terbitan 3 Halaman 76-83

Ahmadi. Edy Anas. 2020. Analisis Trend Penerimaan Dan Efektivitas Pajak Hotel Dan Pajak Restoran Di Kabupaten Bojonegoro Tahun 2016-2020 (Studi Kasus Pada Dinas Pendapatan Daerah Kabupaten Bojonegoro). Sultanist: Jurnal Manajemen Dan Keuangan. Jilid 8. Terbitan 2. Halaman 182-192

Ahmadi. Edy Anas. 2018. Analisa Biaya Bahan Baku Dan Biaya Distribusi Terhadap Pendapatan Pada UD. Sumber Rejeki Di Sukodadi Lamongan. Jurnal Ilmiah Manajemen Dan Bisnis. Jilid 19. Terbitan 1

Bambang Riyanto, 2001:329, Pengertian tentang rasio keuangan. Jakarta: Salemba Empat

Bushee, 1998 dalam Pratiwi, 2010. Pengumpulan informasi dan menentukan harga atas dampak keputusan manajerial secara tepat. Cai et. al., 2001, dalam Faisal, 2005, hubungan berlawanan antara kinerja saham dengan kepemilikan saham institusional.

Demsetz dan Lehn, 1985 dalam Faisal, 2005, konsentrasi kepemilikan perusahaan untuk menghilangkan masalah keagenan. Jakarta: Salemba Empat

Emrinaldi, 2007, masalah keagenan dan terjadinya peningkatan pada kepemilikan manajerial. Yogyakarta: Salemba Empat.

Erich A Helfert, 1996 : 87, indikator kesehatan keuangan. Yogyakarta: Salemba Empat.

Erlina, srimulyani, Metodologi Penelitian Bisnis, USU Press. Medan:2007.Hanafi, 2000, manfaat informasi prediksi kebangkrutan. Yogyakarta.

Finance.detik.com "industri manufaktur kena dampak pandemi kemenperin evaluasi kebijakan" (26 September 2020).

Hidayat, Sedarmayanti. 2002. Metodologi Penelitian. Mandar Maju. Bandung Ika. 2002. "Analisis Rasio Keuangan Untuk Menilai Kinerja Keuangan Pada Perusahaan Rokok (Studi Kasus Pada PT. Gudang Garam Tbk dan PT. Hanjaya Mandala Sampoerna Tbk)". Skripsi Fakultas Ekonomi Universitas Sumatera Utara.

Harnanto,1984, faktor-faktor penyebab terjadinya kebangkrutan. Medan.M Purba, D Simanjutak, Y Malau, W Sholihat, E Ahmadi. 2021. The Effect Of Digital Marketing And E-Commerce On Financial Performance And Business SustainaBility Of Msmes During Covid-19 Pandemic In Indonesia. International Journal Of Data And Network Science. Jilid 5. Terbitan 3. Halaman 275-282

Melly Susanti, Kurniati Karim, Meiffa Herfianti, Eska Prima Monique Damarsiwi, Ahmadi. Edy Anas. 2020 Utilization Of Palm Oil Plant As A Creative Business In Supporting The Economy: Making Food Plate. International Journal Of Psychosocial Rehabilitation. Jilid. 24. Terbitan 2 